
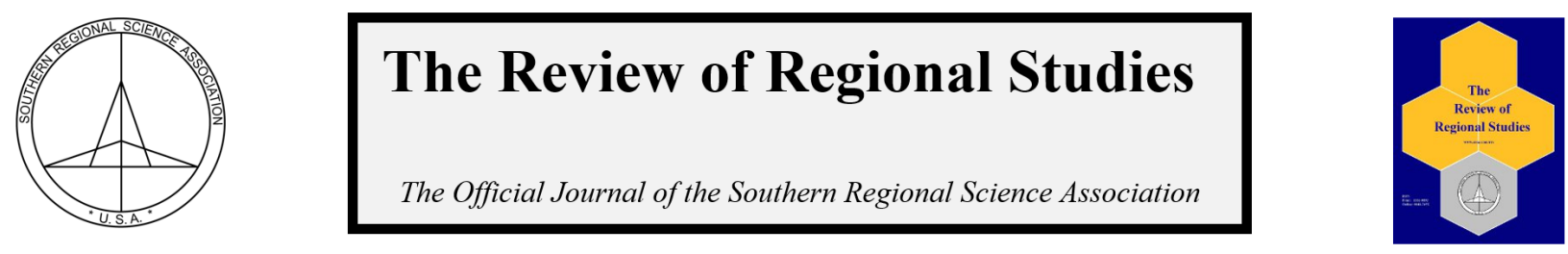

\title{
The Role of Interregional Trade in Virtual Water on the Blue Water Footprint and the Water Exploitation Index in Brazil*
}

\author{
Jaqueline Coelho Visentin ${ }^{\mathrm{a}}$ and Joaquim José Martins Guilhoto ${ }^{\mathrm{a}, \mathrm{b}}$ \\ ${ }^{a}$ Faculdade de Economia, Administração e Contabilidade, University of São Paulo, Brazil \\ ${ }^{b}$ Organization for Economic Co-operation and Development (OECD)
}

\begin{abstract}
Brazil is known for its abundant water supply. However, an uneven spatial distribution of water and strong concentration of economic activities has caused some regions to face water restrictions. The objective of this research is to identify the main water users in Brazil, in terms of virtual blue water, and the impacts of the water use pattern on the regional Water Exploitation Index. Among the main results, the hydrographic basin Tietê was identified as the largest responsible basin for virtual blue water demand, while the hydrographic basin Litoral AL PE PB was an important virtual water supplier. Virtual blue water flows are largely interregional and a majority of the flows (66 percent) were exports from basins where the water balance indicates potential water restrictions. These results suggest that interregional trade in virtual blue water affects water availability for some Brazilian hydrographic basins, potentially undermining water security.
\end{abstract}

Keywords: blue water footprint, water exploitation index, input-output model, hydrographic basin

JEL Codes: Q5, R1

\section{INTRODUCTION}

Water is a non-renewable resource and is essential to all forms of life on the planet. More than 97 percent of the Earth's water supply is in oceans, saline lakes, and saline groundwater, while only 2.5 percent is freshwater ( 1.7 percent in glaciers and ice caps and 0.8 percent in fresh groundwater, fresh surface water, and other freshwater (Shiklomanov, 1993). Human health is directly dependent on the availability of fresh, clean water. Although the hydrological

\footnotetext{
${ }^{*}$ The contents of this publication express the views of this author and do not necessarily represent the views of OECD or of its member countries. Acknowledgements: The authors are grateful to FBB (Brazilian Bank Foundation), MMA (Ministry of Environment), ANA (Brazilian Water National Agency) and FUNARBE (Viosa University Support Foundation) for providing the water consumption coefficients on agriculture and industry sectors. Corresponding Author: Jaqueline Coelho Visentin, E-mail: coelhovisentin@gmail.com
} 
cycle ensures that the volume of water on the Earth remains, more or less, constant over time, local availability of fresh drinking water is not unlimited.

According to the United Nations Environment Programme, 450 million people in 29 countries suffered from water shortages in 2008 and by 2025 two out of every three people will live in areas of water stress United Nations Environment Programme 2e (2008). The primary driving forces of observed restricted water availability are anthropogenic in origin and include population growth, growth in economic activity, rural exodus, and pollution (Schlosser et al., 2014). Often, water withdrawal exceeds its replacement rate (Hoekstra et al., 2011).

According to the National Water Agency (ANA), it is estimated that Brazil has about 12 percent of the Earth's freshwater availability. According to the Food and Agriculture Organization (FAO) of the United Nations, the Total Actual Renewable Water Resource (TARWR) per inhabitant in Brazil was 41.865 cubic meters $\left(\mathrm{m}^{3}\right)$, while the world mean was $9.802\left(\mathrm{~m}^{3}\right)$ in 2011 (Agência Nacional de Águas, 2018). However, there is an uneven spatial distribution of this resource across the country. Roughly 80 percent of Brazil's water resources are concentrated in the northern region, where only 5 percent of the national population resides, while regions near the Atlantic Ocean have more than 45 percent of the population but less than 3 percent of the country's water resources (Agência Nacional de Águas, 2018).

Concentration of population and economic activity along with uneven spatial distribution of water resources have caused some regions to face reduced water availability. The goal of this research is to identify the main water users in Brazil using the Blue Water Footprint approach and to identify the impacts of the water use pattern on the water balance. Section 2 reviews the literature and methods are described in Section 3. Results are presented and discussed in Section 4 and Section 5 concludes.

\section{LITERATURE REVIEW}

Research on freshwater use in Brazil has recently increased. However, information is often given at aggregated sectoral and regional levels. Generally, research considers only the volume of water directly incorporated in production and does not consider the amount of water embodied in the final product through interindustry purchases.

The Water Footprint concept provides a more complete approach to studying total water supply and demand. This method is employed by the Water Footprint Network (WFN), a global researcher network founded in 2008. The Water Footprint measures the volume of water embodied in products according to a bottom-up, engineering-based method of accounting, Life Cycle Analysis (LCA). According to this literature, the Water Footprint is composed of three types of water: Blue, Green, and Grey water. Blue water refers to the disposable water in surface and groundwater, Green water refers to rainwater, and Grey water is the water volume necessary to dilute water pollutants. Based on Hoekstra et al. (2011), the Water Footprint is equal to the total water volume consumed to produce final goods, i.e. water measured along the entire supply chain. Through this approach, it is possible to identify the water type used, as well as where and when it was employed.

(C)Southern Regional Science Association 2019. 
Consumption refers to the loss of available water from a basin, which can occur when water evaporates, returns to another basin or to the sea, or is incorporated in a product (Hoekstra et al., 2011). Virtual Water is similar to the Water Footprint. According to Allan (1993), Virtual Water refers to the total volume of water incorporated in the product. In general, the Virtual Water concept is employed when examining international and interregional flows. For example, if a region exports or imports a product, it is also exporting or importing the water embodied within the product. Given the numerous challenges associated with the sustainable use of natural resources, research has examined whether measurement and assessment of Virtual Water flows can improve water availability.

Several large studies of Virtual Water flow within international trade have included Brazil (Hoekstra and Hung, 2002; Chapagain and Hoekstra, 2003; Zimmer and Renault, 2003; Hoekstra and Mekonnen, 2012), each concluding that Brazil is a major net exporter of Virtual Water. Given Brazil's abundant water resources and status as a net exporter of Virtual Water, it has been the sole focus of only a few studies (Picoli, 2016; Gelain, 2014; da Silva et al., 2016). Picoli (2016) studied the Green Water Footprint of agricultural sectors and the Blue Water Footprint of industrial activities using an input-output model with a database different than that employed by the WFN. Even so, the results corroborate with others, showing that Brazil is an important Virtual Water exporter. Gelain (2014) and da Silva et al. (2016) estimated the Virtual Water international trade balance of the Brazilian States (UF). Gelain (2014) examined trade in agricultural products for 1997 and 2013 and da Silva et al. (2016) studied trade in agricultural and livestock products in 2009. These studies both indicated that Brazil was a net exporter of Virtual Water, especially the southeast region.

All of the reviewed research focused on the Virtual Water embodied in international trade, neglecting the important component of Virtual Water embodied in domestic, interregional trade (Hoekstra and Hung, 2005). Furthermore, the reviewed literature focusing on Brazil defined regions of Brazil based on administrative boundaries such as UF. However, to produce useful information to assess the impact of water use on water availability and, ultimately, some measure of sustainability, it is important to consider watershed boundaries.

Most research on Brazil focuses on Virtual Water embodied in agricultural and livestock products and does not consider the totality of the goods and services produced in the economy. The agricultural and livestock products are water intensive and therefore very important with respect to their share of the national or regional Water Footprint and in the Virtual Water flow. However, the results do not offer a complete measurement of the water use pattern of the economy as a whole.

The review of the literature also identified that, in general, different types of water were applied: Blue, Green, or Grey. While the research provides useful insights into the water use dynamic, examining the Blue, Green, and Grey water simultaneously can lead to confusion in terms of policy implications. Although the different types of water are interdependent, from the policy maker's point of view it seems more feasible to treat them separately. Therefore, it is suggested that research focus on one water type.

Regarding the methodologies and databases used in most of the mentioned studies, the data and methodology are based on detailed information on the Virtual Water incorporated in each stage of the individual productive processes. However, they do not map the entire 
production chain and, therefore, do not identify the use of the goods and services by intermediaries and end users. Thus, it is not possible to identify the main agents responsible for the water withdrawal, consumption, and return (Feng et al., 2011).

As an alternative methodology, the input-output model allows for calculating the Water Footprint along the entire production chain, be it regional, national, or global. Thus, it becomes possible to identify the main agents responsible for water use in the studied economy. It is important to note that the databases used by some of the mentioned research are from the WFN. However, these data might not reflect the climate heterogeneities of the regions that make up a large country such as Brazil.

This research aims to calculate the Blue Water Footprint to identify the main water users in Brazil and the impacts of the water use pattern. This analysis includes examining effect of the Interregional Trade in Virtual Water (ITiVW), on the local Water Exploitation Index (WEI), a quotient between water withdrawal and water availability ${ }^{1}$.

In regional input-output systems research, interregional trade usually refers to trade flows across domestic, regional boundaries, while the terms export and import typically refer to foreign trade that crosses national boundaries (Miller and Blair, 2009). In this research, the Virtual Water hydrography basins' interregional export is equal to the sum of the Virtual Water embedded in the production of goods and services demanded by other Brazilian watersheds' domestic consumption and the Virtual Water embedded in the production of goods and services demanded by international consumption. This modification was made to estimate the share of water extracted destined for the production of goods and services demanded by other regions - be these Brazilian watershed regions or other countries - in relation to the total water extracted. This allowed for the estimation of the impact of water withdrawals used in the production of goods and services to meet other regions' demand on the local water balance. Therefore, the interregional flow of Virtual Blue Water between Brazilian hydrographic basins has been estimated without distinguishing if this flow is directed to the domestic or international market.

This research addresses the identified gaps in the literature on water use in Brazil by offering insights for water resource management and, especially, for the National Water Resources Plan (PNRH). The results can contribute to a better understanding of the regional economic structures that affect local and foreign water use and its availability and thereby, assisting the evaluation of public policies aimed at sustainable water management.

\section{METHODOLOGY}

The methodological approach follows three steps. In the first step, an interregional inputoutput model and its multipliers were constructed (see Miller and Blair (2009)). An interregional input-output matrix was built for the year 2009, which considers 50 economic activities and 56 PNRH hydrographic basins, as described in Figure 1 and Table 1.

The methodology and data employed are partially described in Guilhoto et al. (2017) and based on the national input-output system estimated according to Guilhoto and Sesso-Filho

\footnotetext{
${ }^{1} \mathrm{WEI}_{b}=\mathrm{W}_{b} / \mathrm{W}_{a b}$, where $b$ is basin, $\mathrm{W}_{b}$ is water withdrawn in basin $b$, and $\mathrm{W}_{a b}$ is water availability in
} basin $b$

(C)Southern Regional Science Association 2019. 


\section{Figure 1: 56 National Water Resources Plan Hydrographic Basins}

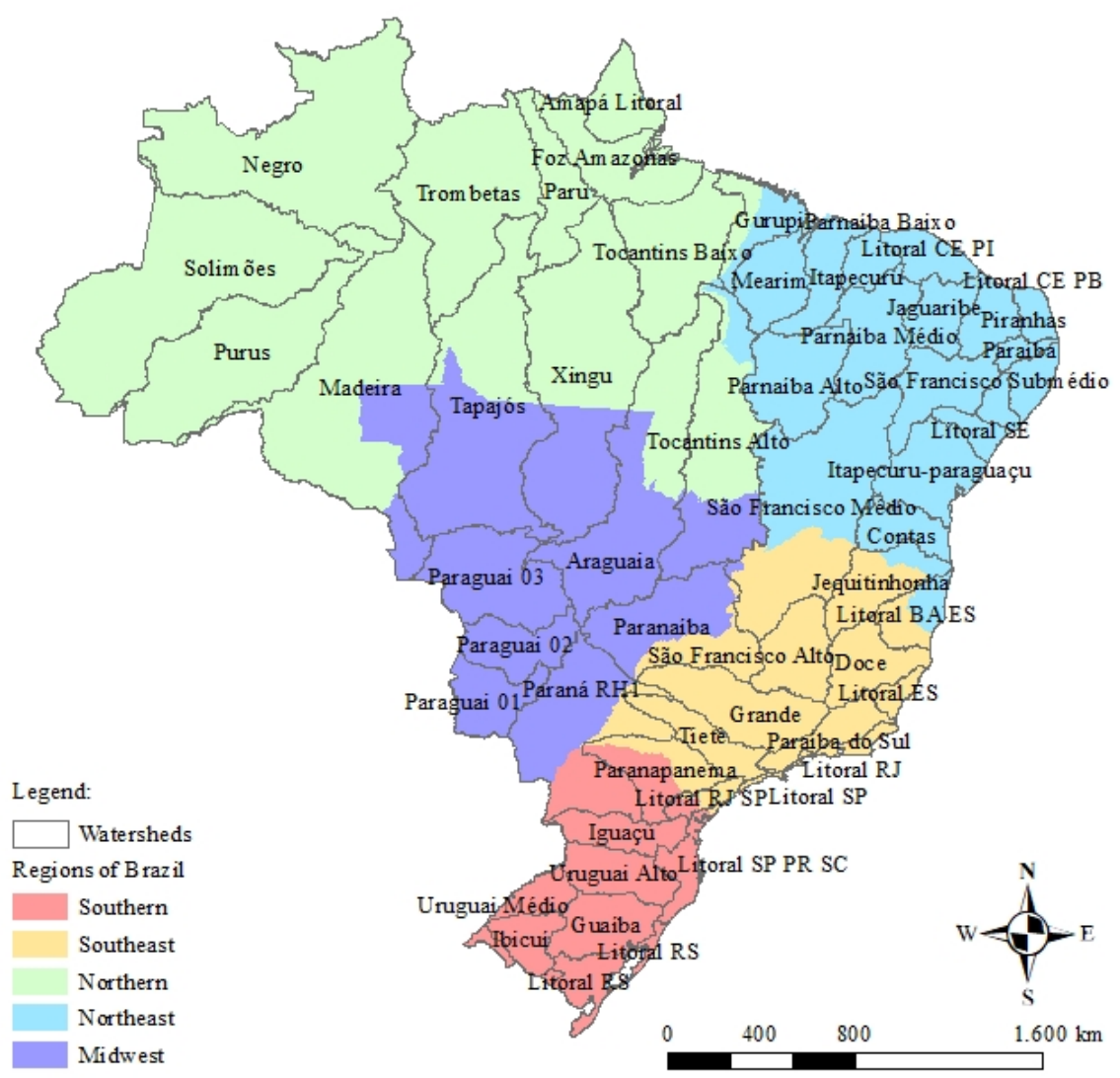

Source: Agência Nacional de Águas (2013b)

(2005) and Guilhoto et al. (2010).

According to Guilhoto et al. (2017), it is necessary to disaggregate the data for each UF to their respective municipalities. Given the lack of data to estimate the economic structure of the industries at the municipality level, we assumed that the industries in the municipalities have the same structure as the UF to which they belong.

The estimated inter-municipal input-output model was then aggregated according to the municipal composition of the watersheds (Instituto Brasileiro de Geografia e Estatística (Brazilian Institute of Geography and Statistics), 2015). In this way, the interregional inputoutput system was obtained in terms of the hydrographic basins.

On the one hand, the structure of production, in terms of the technical coefficients, which refer to the cost shares of the inputs, of a given industry in the municipalities of a given state are similar. On the other hand, the technical coefficients relating to water consumption, as detailed below and in the appendices, were estimated specifically for each industry in each watershed. Therefore, the water consumption coefficients reflect the different needs of each industry in each watershed, reflecting the different patterns of water consumption for 
Table 1: The 50 Economic Activities Studied

\begin{tabular}{llll}
\hline \hline 1 & Rice & 26 & Beverages \\
2 & Maize & 27 & Textile and others \\
3 & Sugar cane & 28 & Leather and shoes products \\
4 & Soya bean & 29 & Wood and other products \\
5 & Citrus fruits & 30 & Oil refining and coke \\
6 & Other fruits & 31 & Alcohol \\
7 & Coffee & 32 & Chemical and other elements \\
8 & Other crops & 33 & Steel, non-ferrous metallurgy \\
9 & Forestry & 34 & Machines and equipment \\
10 & Other forestry activities & 35 & Electrical and other material \\
10 & Cattle & 36 & Cars and others \\
12 & Raising of other animals & 37 & Furniture industry and miscellaneous \\
13 & Swine & 38 & Electric power (hydraulic) \\
14 & Poultry & 39 & Electric power (other sources) \\
& Hunting, trapping and related & 40 & Electric power (sugar cane) \\
& service activities & & Transmission and distribution of \\
16 & Oil and natural gas & 41 & electricity, piped gas \\
17 & Mining of metal ores & 42 & Water and sewarage \\
18 & Other mining and quarrying & 43 & Cleaning activities \\
19 & Processing and preserving of meat & 44 & Construction \\
20 & Manufacture of vegetable oils & 45 & Trade \\
21 & Manufacture of dairy products & 46 & Transport \\
22 & Processing of vegetable products & 47 & Other services \\
23 & Coffee industry & 48 & Education and health \\
24 & Other food products & 49 & Domestic services \\
25 & Manufacture of sugar & 50 & Public services \\
\hline \hline
\end{tabular}

Source: Authors' calculations

industries in different watersheds.

The second step consisted of estimating the direct technical coefficients of withdrawal, consumption, and return of Blue Water for each hydrographic basins economic activities. Among the different purposes for which water resources are employed, the two overarching usages are consumptive and non-consumptive. The first concerns the volume of water withdrawn that is consumed in the productive process and is not returned to the watercourse. The second concerns cases where the use of water occurs in the water body itself (Agência Nacional de Águas, 2013a). The main consumptive uses are the water supply for human use, animal feed, industrial use, and irrigation. The most important non-consumptive uses are hydroelectric generation, navigation, fishing and aquaculture, protection of aquatic life, and tourism and recreation (Agência Nacional de Águas, 2013a). In the estimation of technical coefficients, only the consumptive use of water was considered. 
Although this research produces an estimation on the withdrawal, consumption, and return of water, the analysis of the results is only concerned with the withdrawal. This is because this research seeks to be useful especially to the PNRH. Also, it was taken into account that "[The demand for water corresponds to the withdrawal flow. [...]" (Agência Nacional de Águas (2013a), p.87) and, in general, it is this variable that is employed for water resource management in Brazil. ${ }^{2}$

To calculate the direct technical coefficients of water use by the agricultural sectors, which refer to sectors 1 to 9, data from the Fundação Banco do Brasil et al. (2011) was used, according to the procedures described in Appendix B. Other forestry activities (sector 10) cover native vegetation resources exploration that includes the collection of products such as woods, rubber, seeds, fibers, fruits and roots, among other (Instituto Brasileiro de Geografia e Estatística (Brazilian Institute of Geography and Statistics), 2014) This activity is not considered intensive in water use, so, like Ussami and Guilhoto (2018), its direct use of Blue Water was treated as equal to zero.

For animal feed, the methodology used in Operador Nacional do Sistema Elétrico and Consórcio Fahma/Dreer (2005) was employed. The direct technical coefficients of Blue Water use for the livestock sectors (sectors 11-14) were calculated as described in Appendix C. Hunting, trapping, and related activities (sector 15), that refer to fishing and aquaculture activities, are not intensive in the consumptive use of water. Thus, its Blue Water use direct technical coefficient was treated as equal zero. The Blue Water use direct technical coefficient estimation for the industrial activities (sectors 16-37) is detailed in Appendix D. The estimation procedure of the direct coefficient of water use for the water and sewage sector (sector 42) is described in Appendix E.

Sectors 38 to 40, which are related to the production of Electric Energy, are activities that are not intensive in the consumptive use of water, so that their direct technical coefficients of extraction, consumption, and return were treated as equal to zero. The same assumption was made for the sectors transmission and distribution of electricity and piped gas (41), cleaning activities (43) and construction (44), as well as for the service sectors (sectors 4550). Since these activities, in most cases, do not capture water directly from the water bodies and consume water only from the water supply system, it was assumed that their direct technical coefficients of withdrawal, consumption, and return of water were zero.

In third and last step, the water flow and water use were estimated. The Virtual Blue Water embodied in the final demand was identified through the application of the direct technical coefficients of water use in the interregional input-output matrix, as described in Miller and Blair (2009) and below as:

$$
\begin{gathered}
G=\hat{C} * L \\
V w=G * Y
\end{gathered}
$$

\footnotetext{
${ }^{2}$ All the information on the strategies adopted for the data treatment, as well as the detailed results of all the steps of this research are available on the University of São Paulo Regional and Urban Economics Lab (NEREUS) homepage, https://www.usp.br/nereus/?fontes=dados-outros. As data on consumption and return were also estimated, they are included in this reference.
}

(c) Southern Regional Science Association 2019. 
Where:

$G$ is a matrix whose elements are the multipliers of water use (withdrawal, consumption, or return);

$\hat{C}$ is a diagonal matrix with the elements of the main diagonal representing the direct technical coefficients of water use (withdrawal, consumption, or return);

$L$ is the Leontief inverse matrix;

$V w$ is a matrix with the volume of Virtual Blue Water embodied in the final demand;

$Y$ is a matrix that contains the values of the total final demand. Namely, the domestic and the international final demand.

Therefore, with the matrix that contains the volume of Virtual Blue Water embodied in the final demand, it is possible to map the intraregional and interregional flows.

Finally, the Blue Water Footprint of economic activity in each hydrographic basin is estimated according to the methodology described in Feng et al. (2011) and below as:

$$
\begin{aligned}
& W F_{d}=W F_{d o m}+W F_{i m p} \\
& W F_{s}=W F_{d o m}+W F_{\text {exp }}
\end{aligned}
$$

Where:

$W F_{d}$ is the Blue Water Footprint by demand side, or Virtual Blue Water demand, of an economic activity or a watershed. It refers to the volume of Virtual Blue Water embodied in the sector or watershed consumption;

$W F_{d o m}$ is the Domestic Blue Water Footprint of a sector or a watershed. It is equal to the volume of Virtual Blue Water contained in goods and services produced and consumed by this sector or watershed;

$W F_{i m p}$ is the Imported Blue Water Footprint of a sector or a watershed. It refers to the volume of Virtual Blue Water contained in goods and services imported by a sector or a watershed from other basins;

$W F_{s}$ is the Blue Water Footprint by supply side or Virtual Blue Water supply. It refers to the volume of Virtual Blue Water embodied in the domestic production of a sector or a watershed;

$W F_{\text {exp }}$ is the Exported Blue Water Footprint of a sector or a watershed. It refers to the volume of Virtual Blue Water contained in the interregional exports of goods and services of a sector or a watershed.

Consequently, the main water users in Brazil and the impacts of water use patterns, including the ITiVW, on regional WEI can be identified with the Blue Water Footprint approach.

\section{RESULTS}

The results show, that 60.6 billion $m^{3}$ of Blue Water was withdrawn in Brazil in 2009 of which 39 percent were intraregional flows of Virtual Blue Water $\left(23.4\right.$ billion $\mathrm{m}^{3}$ ).

(c)Southern Regional Science Association 2019. 
On the Blue Water Footprint by demand side, the Tietê hydrographic basin was the region with the greatest demand, accounting for 14 percent $\left(8.7\right.$ billion $\left.\mathrm{m}^{3}\right)$ in 2009 , followed by the Litoral AL PE PB region accounting for 9 percent (5.3 billion $\mathrm{m}^{3}$ ), Grande (7.2 percent), Litoral RJ (7 percent), Paraíba (6 percent), Guaíba (5 percent) and Paraíba do Sul (4 percent). This group was responsible for 52 percent of the Virtual Blue Water demand in Brazil in 2009.

On the Blue Water Footprint by supply side, the Litoral AL PE PB hydrographic basin was the greatest supplier accounting for 13 percent in 2009, followed by Grande (11 percent), Tietê (8 percent), Paraíba do Sul (6 percent), Guaíba (4.6 percent), Paranaíba (4.5 percent) and Litoral RS (4 percent). This group was responsible for 50 percent of the Virtual Blue Water supplied in 2009.

The dependency on imports was analyzed by constructing a type of Water Dependency Index (WDI $)^{3}$ for each hydrographic basin. This type of WDI was named Water Import Dependency Index ${ }^{4}$ and is defined as the quotient of the Imported Blue Water Footprint and the Blue Water Footprint by demand side.

Similarly, no measure was found in the literature that studies export dependency. Therefore, this research proposes the Water Export Dependency Index (WEDI) ${ }^{5}$ defined as the quotient of the Exported Blue Water Footprint and the Blue Water Footprint by supply side. The WIDI results showed that among the 56 watersheds the Blue Water Footprint by demand side was in 48 cases primarily composed of the Imported Blue Water Footprint. Therefore, in most regions the Blue Water Footprint by demand side was interregional.

For example, to meet the final demand for goods and services in the Tietê hydrographic basin, 8.7 billion $\mathrm{m}^{3}$ of water had to be withdrawn of which 6.2 billion $\mathrm{m}^{3}$ were collected from other watersheds (Exported Blue Water Footprint), while 2.5 billion of $m^{3}$ were withdrawn in the region (Domestic Blue Water Footprint).

For the other eight regions, the Blue Water Footprint by demand side was mainly composed of the Domestic Blue Water Footprint and, therefore, the Virtual Blue Water demand was mainly intraregional. These regions are: (i) Tocantins Baixo; (ii) Tocantins Alto; (iii) Doce; (iv) Litoral CE PB; (v) Xingu; (vi) Paraíba do Sul; (vii) Grande; and (viii) Litoral AL PE PB, as shown in Figure 2.

From the perspective of the WEDI, the Blue Water Footprint by supply side was mainly composed of the Exported Blue Water Footprint. In most regions, the Virtual Blue Water supply was interregional. Among the 56 watersheds, 49 allocated more than 50 percent of the Blue Water Footprint by supply side to Virtual Blue Water Interregional Exports.

For example, to meet Brazil's final demand observed in 2009, the Grande hydrographic basin offered 6.6 billion $\mathrm{m}^{3}$ of Virtual Blue Water of which 3.8 billion $\mathrm{m}^{3}$ were for the Virtual Blue Water Interregional Exports and 2.8 billion $m^{3}$ were for the Domestic Blue Water Footprint.

\footnotetext{
${ }^{3}$ It is said to be a kind of WDI, because in the present case the ratio between the gross interregional import of Virtual Blue Water and the total appropriation of Virtual Blue Water of a given region was calculated, instead of considering the net interregional import of Virtual Blue Water, as suggested by the original definition presented in Hoekstra and Hung (2002).

${ }^{4}$ The calculation is described in Appendix A.

${ }^{5}$ The calculation is described in Appendix A.
} 
Figure 2: Water Import Dependency Index - 2009

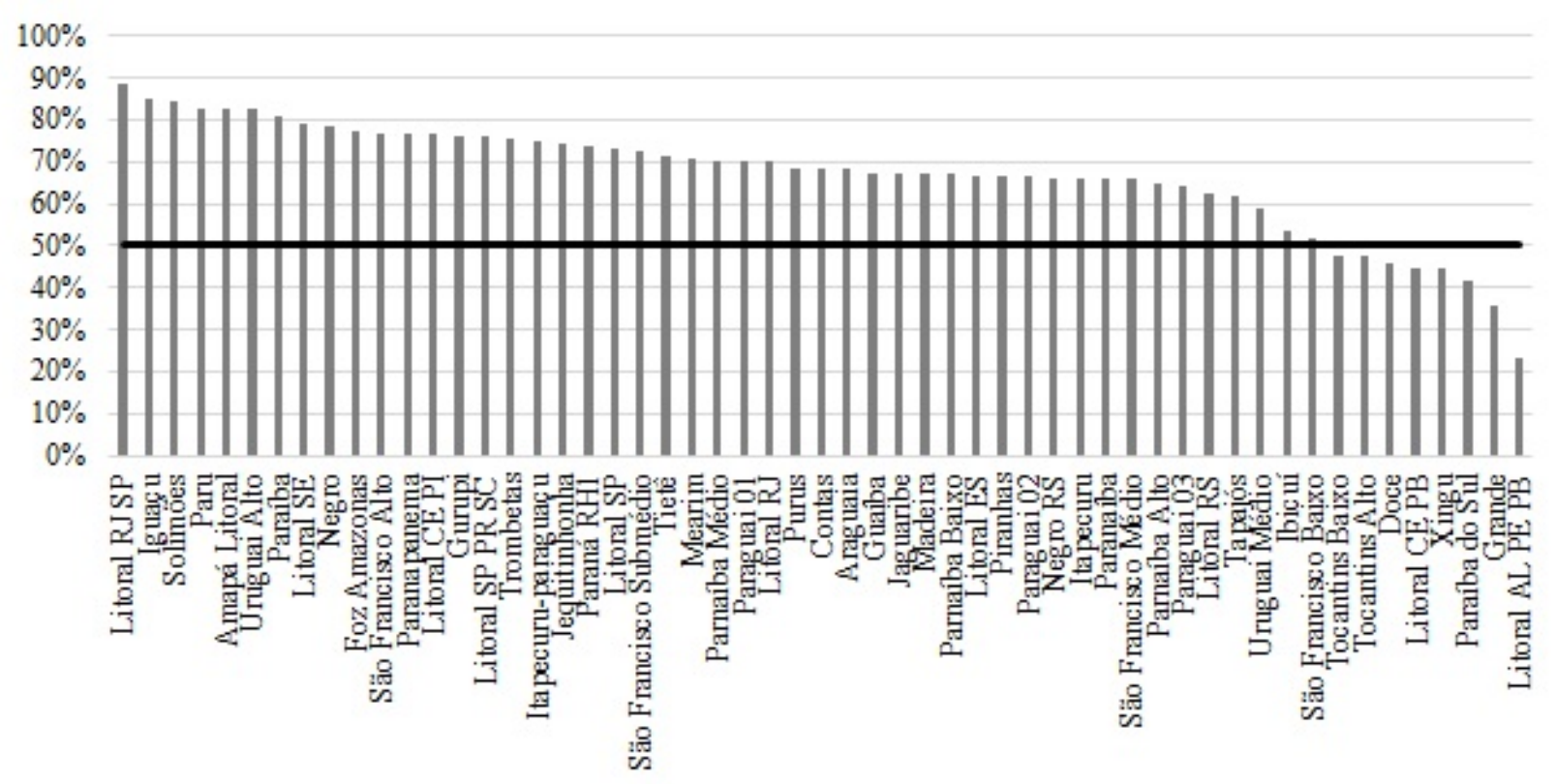

Source: Authors' calculations.

The other seven regions where the Blue Water Footprint by supply side was mainly intraregional are: (i) Tietê; (ii) Litoral AL PE PB; (iii) Litoral ES; (iv) Parnaíba Médio; (v) Litoral RJ; (vi) Mearim; and (vii) Tocantins Baixo, as shown in Figure 3.

Finally, it is important to note, that contrary to the trend observed for most cases, Tocantins Baixo and Litoral AL PE PB were the only regions where the Virtual Blue Water flow was mainly intraregional in both directions.

In terms of the spatial distribution, the watersheds most dependent on Virtual Blue Water interregional imports were mainly concentrated in the northern region. The other river basins were distributed throughout the country. The watersheds most dependent on Virtual Blue Water interregional exports were mainly in the southern, southeast, midwest and northeast regions, as shown in Figures 4 and 5.

According to the results, the Virtual Blue Water demand and supply among the 56 watersheds were mainly interregional in 2009. Given the significant water interdependency among the watersheds, the main regions responsible for the Virtual Blue Water interregional flows are studied in greater detail.

Regarding the Imported Blue Water Footprint, the Tietê hydrographic basin stands out. This region was responsible for 17 percent of the Virtual Blue Water interregional imports in 2009. It was followed by Litoral RJ (8 percent), Paranaíba (7 percent), Guaíba (5.1 percent), São Francisco Alto (5 percent), Itapecuru-paraguaçu (4.7 percent), and Grande (4 percent). These seven regions were responsible for 50 percent of the Virtual Blue Water interregional imports.

(C)Southern Regional Science Association 2019. 


\section{Figure 3: Water Export Dependency Index in 2009}

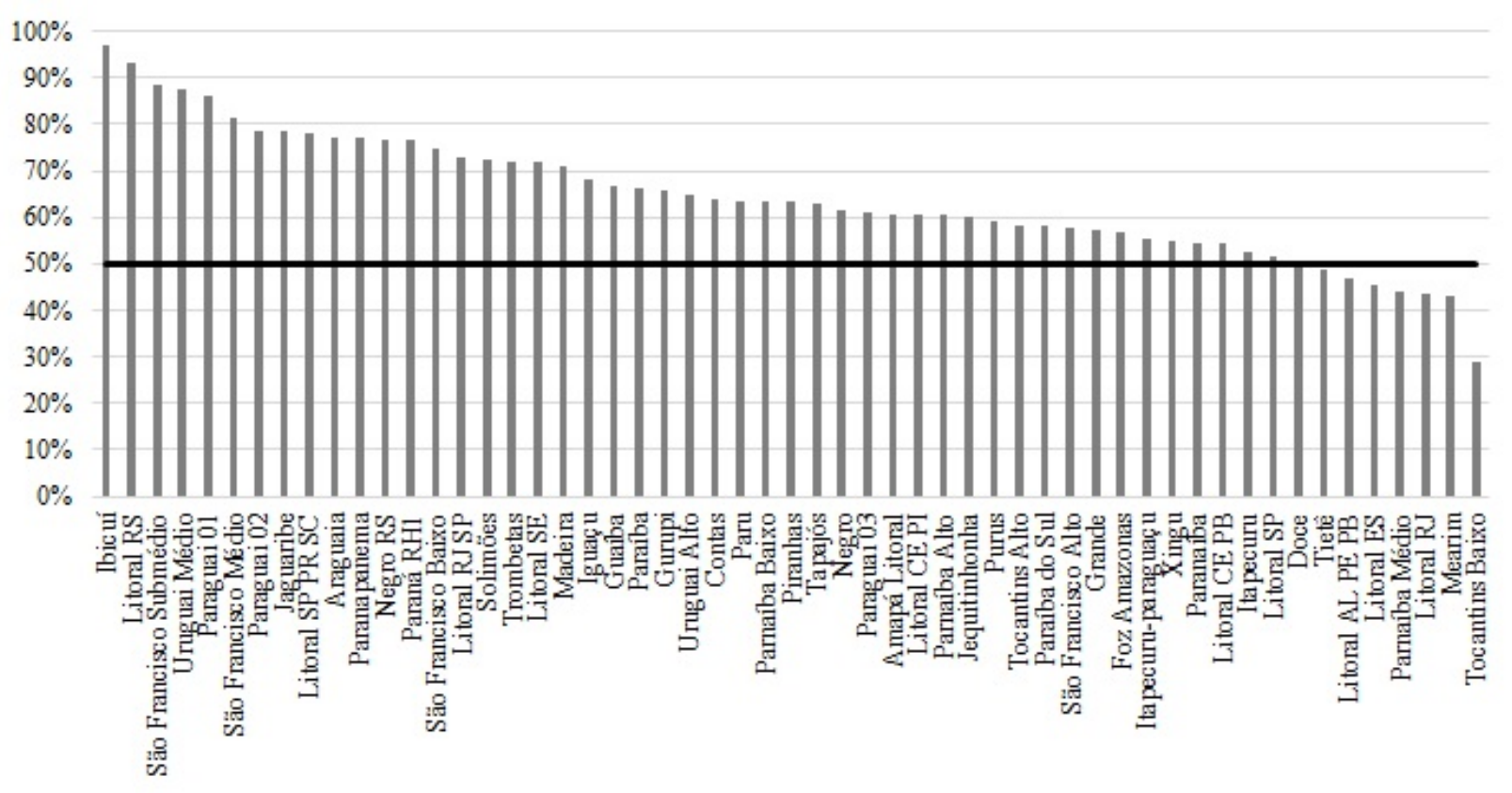

Source: Authors' calculations.

Regarding Exported Blue Water Footprint, exports to the domestic market accounted for 89 percent of the total, while exports to foreign markets accounted for only 11 percent in 2009. The main watersheds were Grande, responsible for 10.2 percent, Litoral AL PE PB (9.7 percent), Tietê (6.5 percent), Litoral RS (5.7 percent), Paraiba do Sul (5.4 percent), Guaíba (5 percent), Ibicuí (4.6 percent), and Paranaíba (4 percent). This group of eight regions accounted for 51 percent of Virtual Blue Water Exports in 2009.

These results show that some important Blue Virtual Water importing watersheds were also important exporters. In an interregional input-output system, these flows can occur for different purposes and can be decomposed by the following Virtual Blue Water uses:

i. Final product;

ii. Intermediate product attributed to the final demand of the destination region;

iii. Intermediate product attributed to the final demand of other regions, including the originating region; and

iv. Intermediate product attributed to the intermediate consumption of other regions, including the originating region.

This system identifies the Virtual Blue Water embodied in the international trade exports to the "Rest of the World," but it does not identify the purpose for which the products and services were used. One of the main objectives of this research is to verify the importance 


\section{Figure 4: Water Import Dependency Index in 2009}

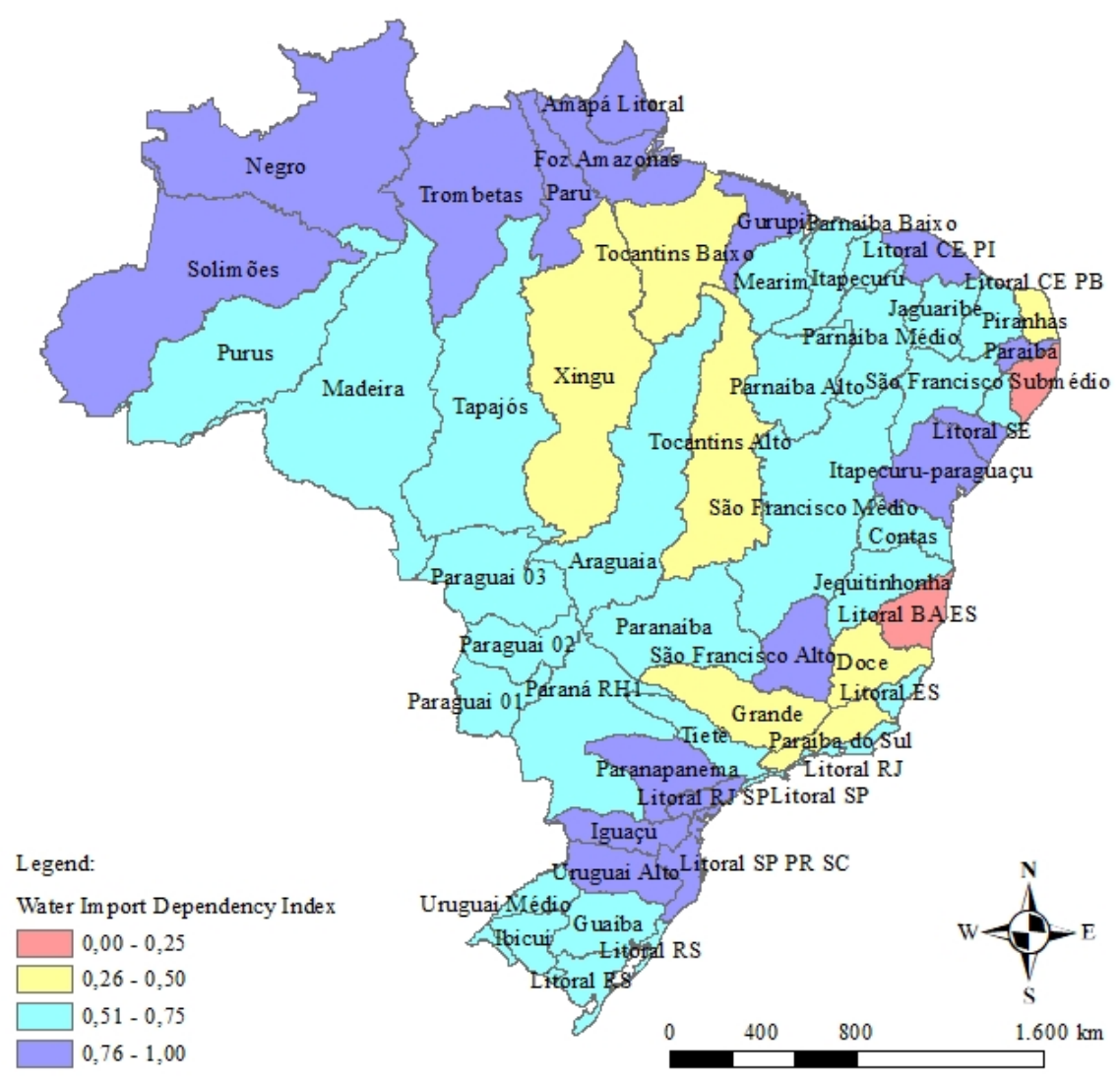

Source: Authors' calculations.

of the interregional trade of Virtual Blue Water on the regional WEI. Therefore, this paper focuses on the estimation of the extracted water employed in the production of goods and services destined to other regions without distinguishing them by their purpose. An important region, in terms of Virtual Blue Water imports, can also be an important Virtual Blue Water exporter for different reasons.

As shown in Figures 6 and 7, the main Imported Blue Water Footprint watersheds are concentrated in the southeast. At the same time, the main Exported Blue Water Footprint watersheds have a wider regional dispersion with a concentration in the southeast and south regions. Furthermore, Litoral AL PE PB, located in the northeast region, stands out in terms of the Exported Blue Water Footprint in 2009.

The results also show which watersheds were net exporters or net importers of Virtual Blue Water in the interregional trade in 2009. Among the 56 regions, 24 were net exporters. Litoral AL PE PB, Grande, Litoral RS, and Ibicuí accounted for 61 percent of the net interregional exports. Thirty-two watersheds were net interregional importers of Virtual Blue Water, including Tietê, Litoral RJ, and São Francisco Alto, which accounted for 51\% of total flows. The interregional trade balance in relation to Virtual Blue Water flows of 


\section{Figure 5: Water Export Dependency Index in 2009}

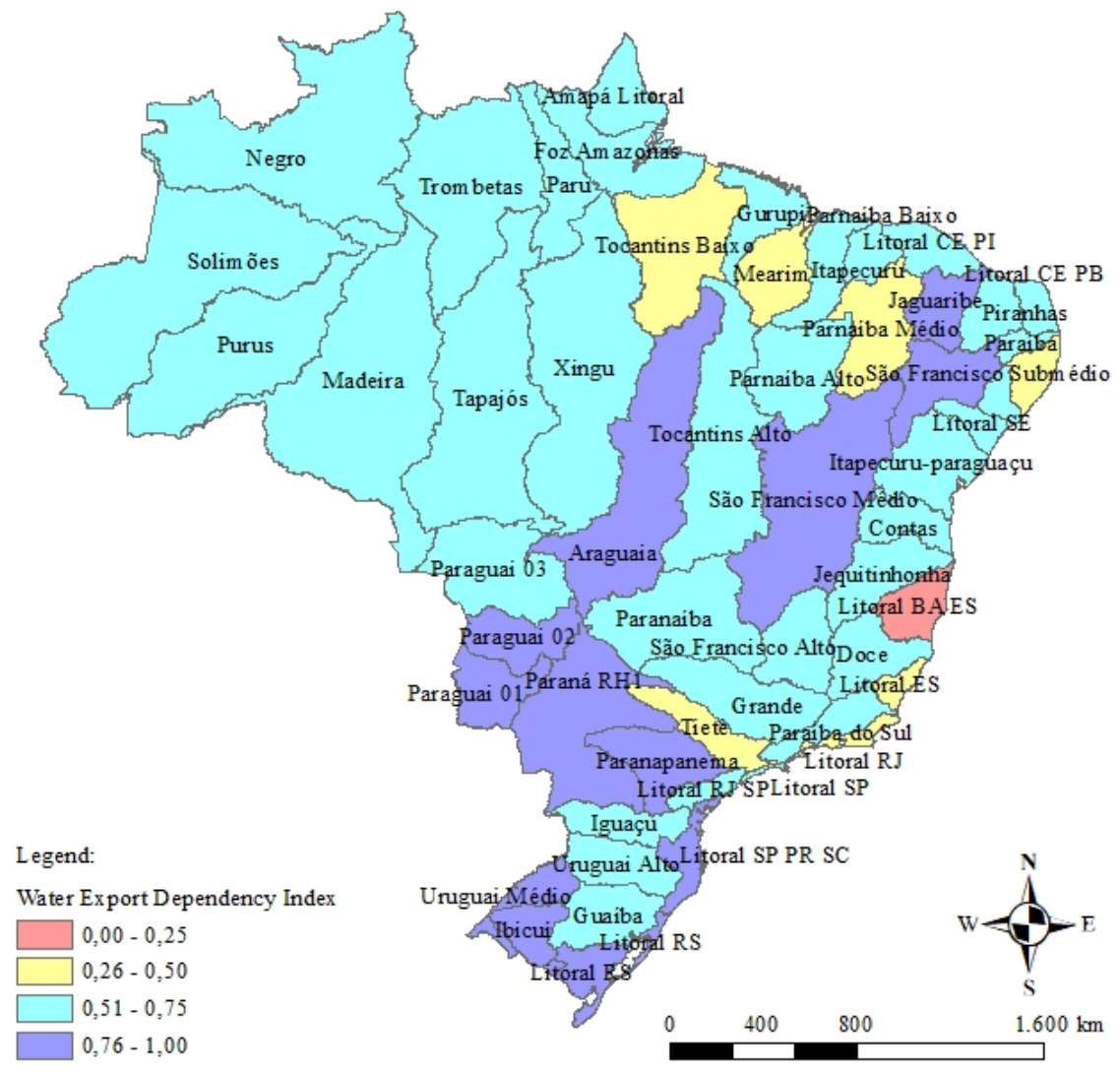

Source: Authors' calculations.

each hydrographic basin is presented in Figure 8.

Given that the structure of the Virtual Blue Water use in the Brazilian watersheds and the Virtual Blue Water flows were mainly interregional in 2009, it is important to analyze the effects of the Blue Water use pattern on local water availability.

According to Hoekstra and Hung (2005), a positive relationship between WEI and WIDI and a negative relationship between WEI and WEDI are expected and have implications on water security. That is, watersheds where WEI is not at a sustainable level should resort to more imports and less exports of Virtual Blue Water. 
Figure 6: Imported Blue Water Footprint in 2009

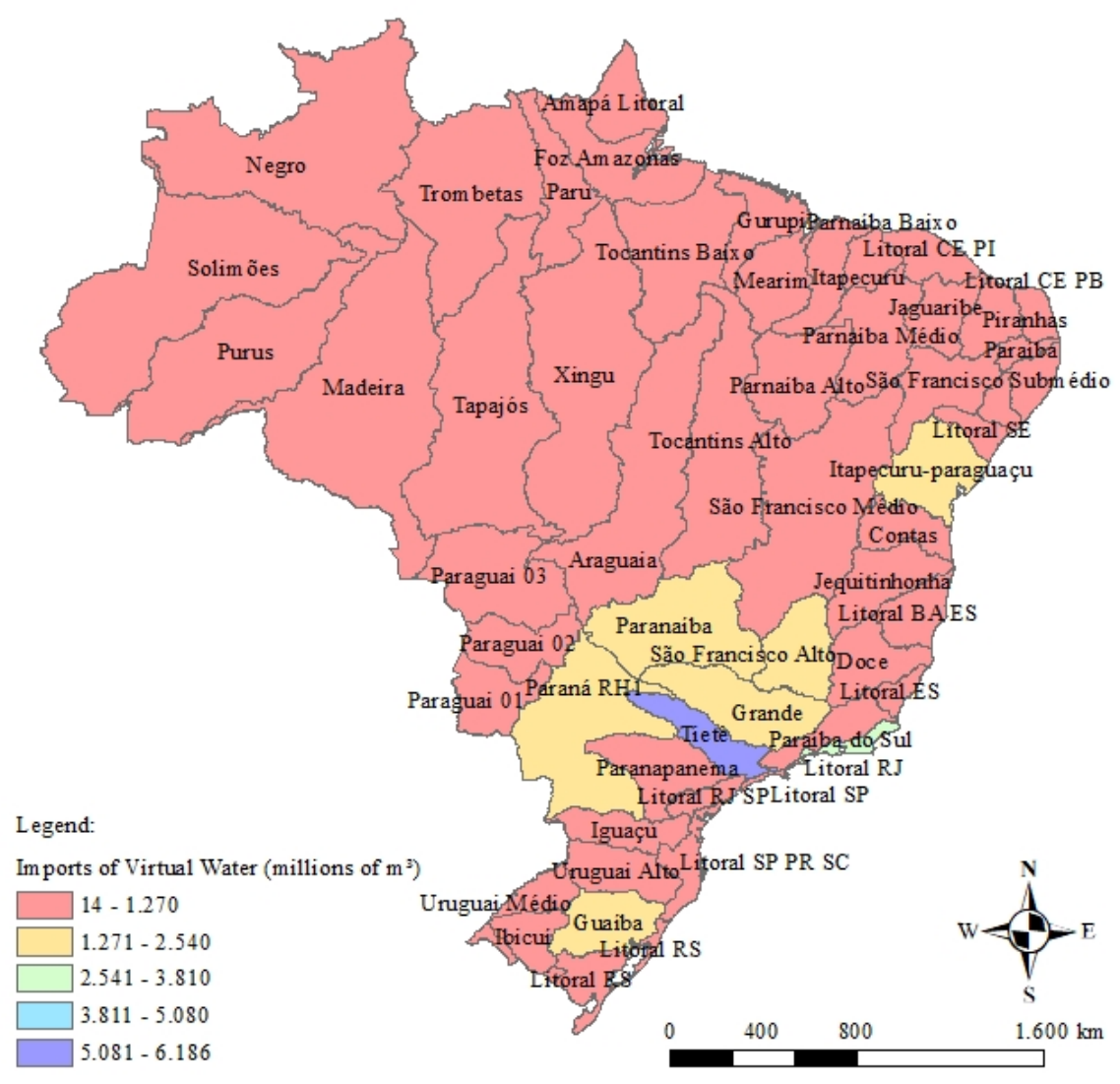

Source: Authors' calculations.

Thus, the $\mathrm{WEI}^{6}$ was estimated for each Brazilian hydrographic basin based on water withdrawal for consumptive uses in 2009 and the water availability in $2006 .^{7} \mathrm{WE}$ assumed that there were no climatic variations that significantly affected the water availability of the

${ }^{6}$ The classification ranges of WEI used by the European Environment Agency and by United Nations are described below, which are also appropriate for the Brazilian case (Agência Nacional de Águas, $2013 a$ ).

a. WEI $<5$ percent - Excellent. Little or no management activity is required. Water is considered a free good;

b. 5 percent $\leq$ WEI $<10$ percent - Comfortable. The situation is comfortable, and management may be needed to solve local supply problems;

c. 10 percent $\leq$ WEI $<20$ percent - Worrying. The management activity is indispensable, requiring the realization of average investments;

d. 20 percent $\leq$ WEI $<40$ percent - Critical. The situation is critical, requiring intense management activity and large investments;

e. WEI $\geq 40$ percent - Very critical. The situation is very critical.

${ }^{7}$ Ministério do Meio Ambiente (2006)

(c) Southern Regional Science Association 2019. 
Figure 7: Exported Blue Water Footprint in 2009

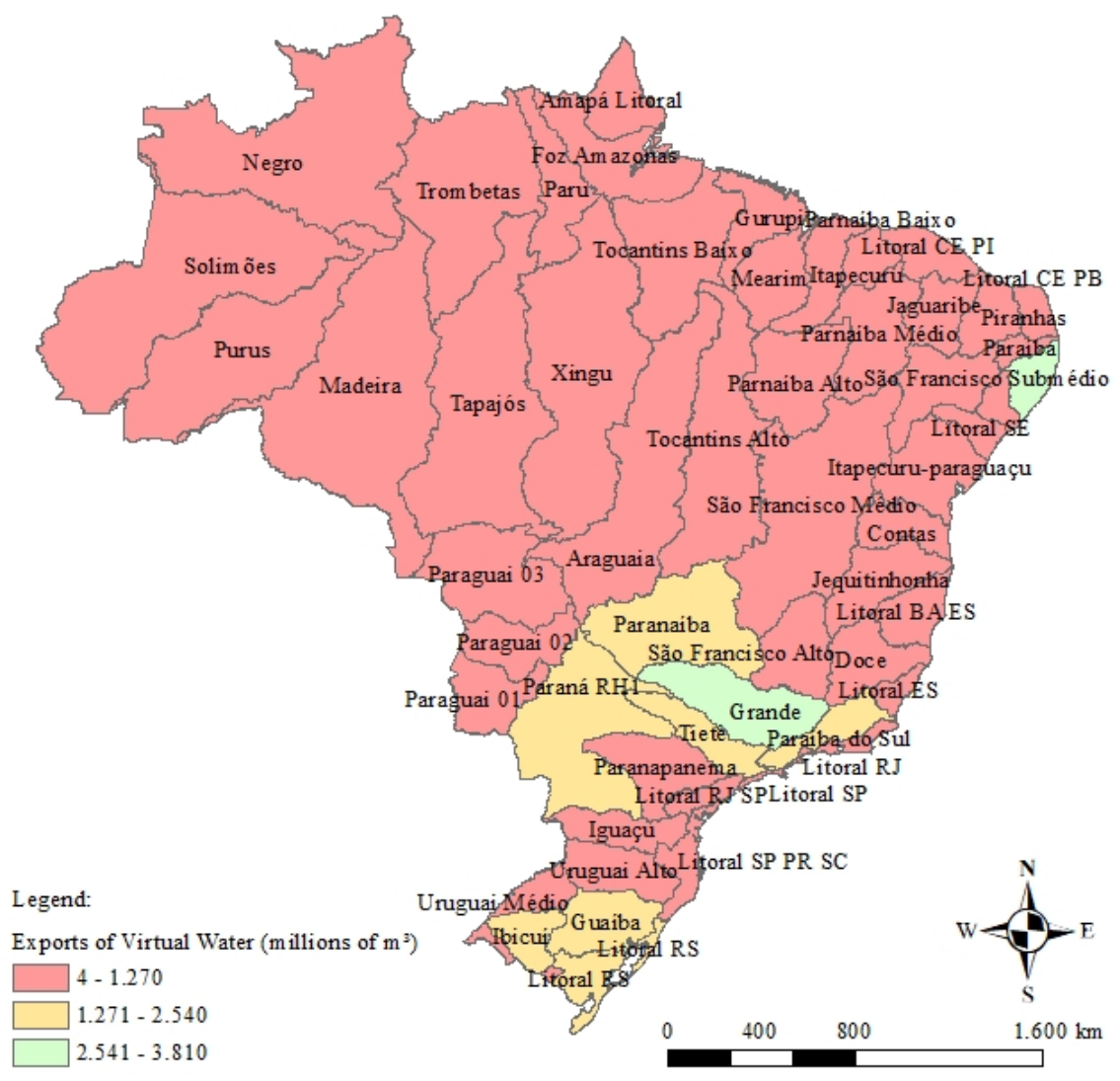

Source: Authors' calculations.

regions between 2006 and 2009. The results are shown in Figure 9.

The results show that 34 watersheds were in an excellent or comfortable situation, five were in a worrying situation, eight regions were in critical condition, and nine watersheds were in a very critical situation in 2009.

The results for the Blue Water Footprint by demand side show that 22 watersheds had a WEI that was worrying, critical, or very critical, and among these 22 watersheds 17 presented a WIDI greater than 50 percent. That is, among the regions that presented a WEI worrying, critical, or very critical situation, more than half of their Virtual Blue Water demand came from interregional imports. This result corroborates what a policy maker would hope for from a water security perspective.

However, in relation to the Blue Water Footprint by supply side, the results showed that among the 22 watersheds, where the WEI were worrying, critical, or very critical in 2009, 17 also had a WEDI greater than 50 percent. That is, most of the watersheds with WEI problems exported more than half of the withdrawn water volume.

Examining this more closely, the following stands out: (i) among the five watersheds where the WEI were worrisome, all presented WEDI greater than 50 percent; (ii) among 


\section{Figure 8: Interregional Trade Balance of Virtual Blue Water in 2009}

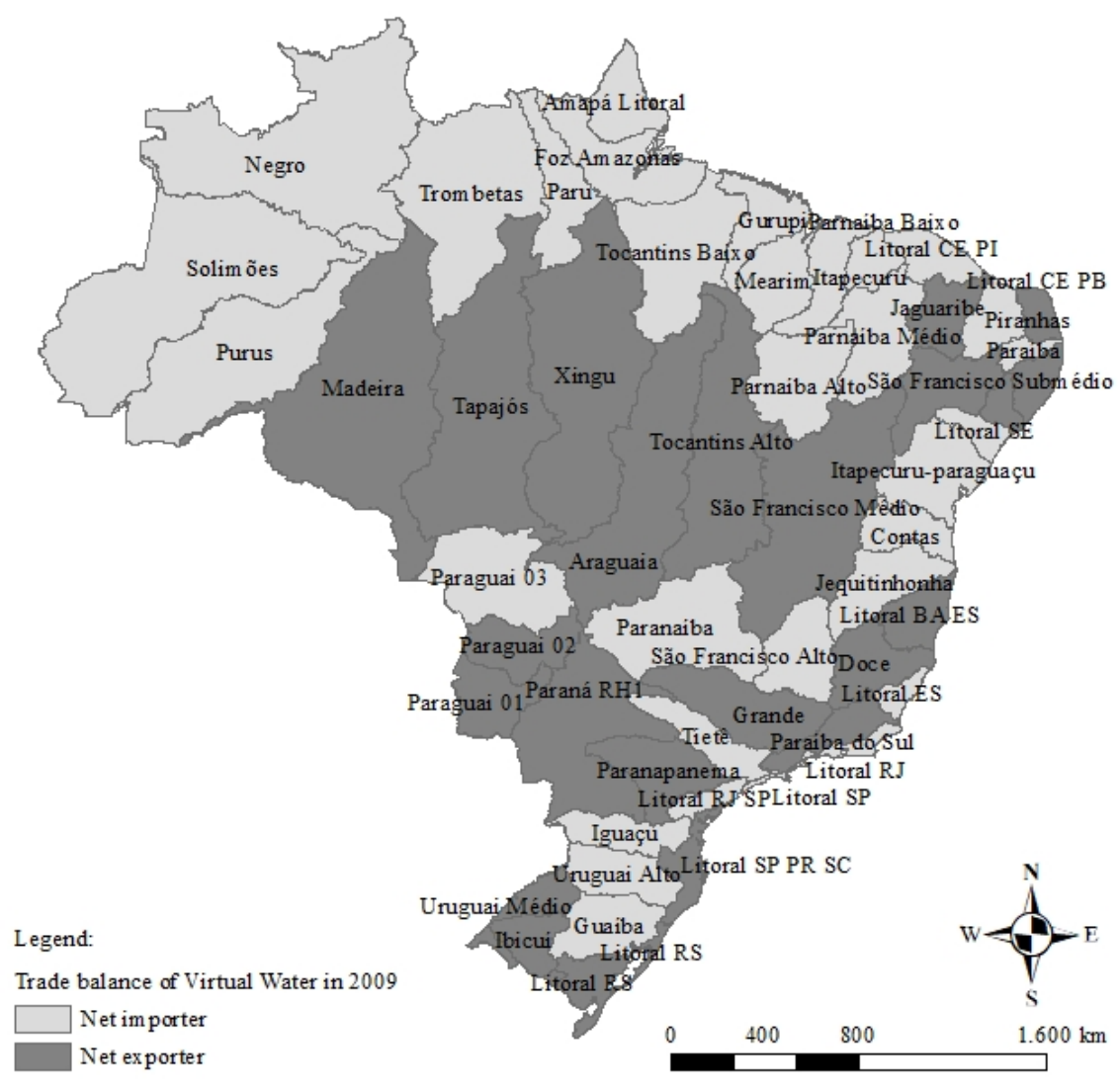

Source: Authors' calculations.

the eight regions with critical WEI, seven showed a WEDI greater than 50 percent; and (iii) among the nine watersheds with very critical WEI, in five the WEDI was greater than 50 percent in the period.

In addition, we found that the main net exporting regions of Virtual Blue Water and the main exporters of Virtual Blue Water are also regions where the water balance was critical or very critical in 2009.

The results show that 66 percent of Virtual Blue Water exported among the regions came from watersheds where the WEI was somehow compromised. That is, 7 percent of the interregional exports of Virtual Blue Water came from regions where the WEI was worrisome, 28 percent came from watersheds with critical WEI and 31 percent originated from watersheds where WEI was very critical in 2009. Therefore, we conclude that most Virtual Blue Water interregional exports threatened local water availability in 2009 affecting the water security. 
Figure 9: Water Exploitation Index in 2009

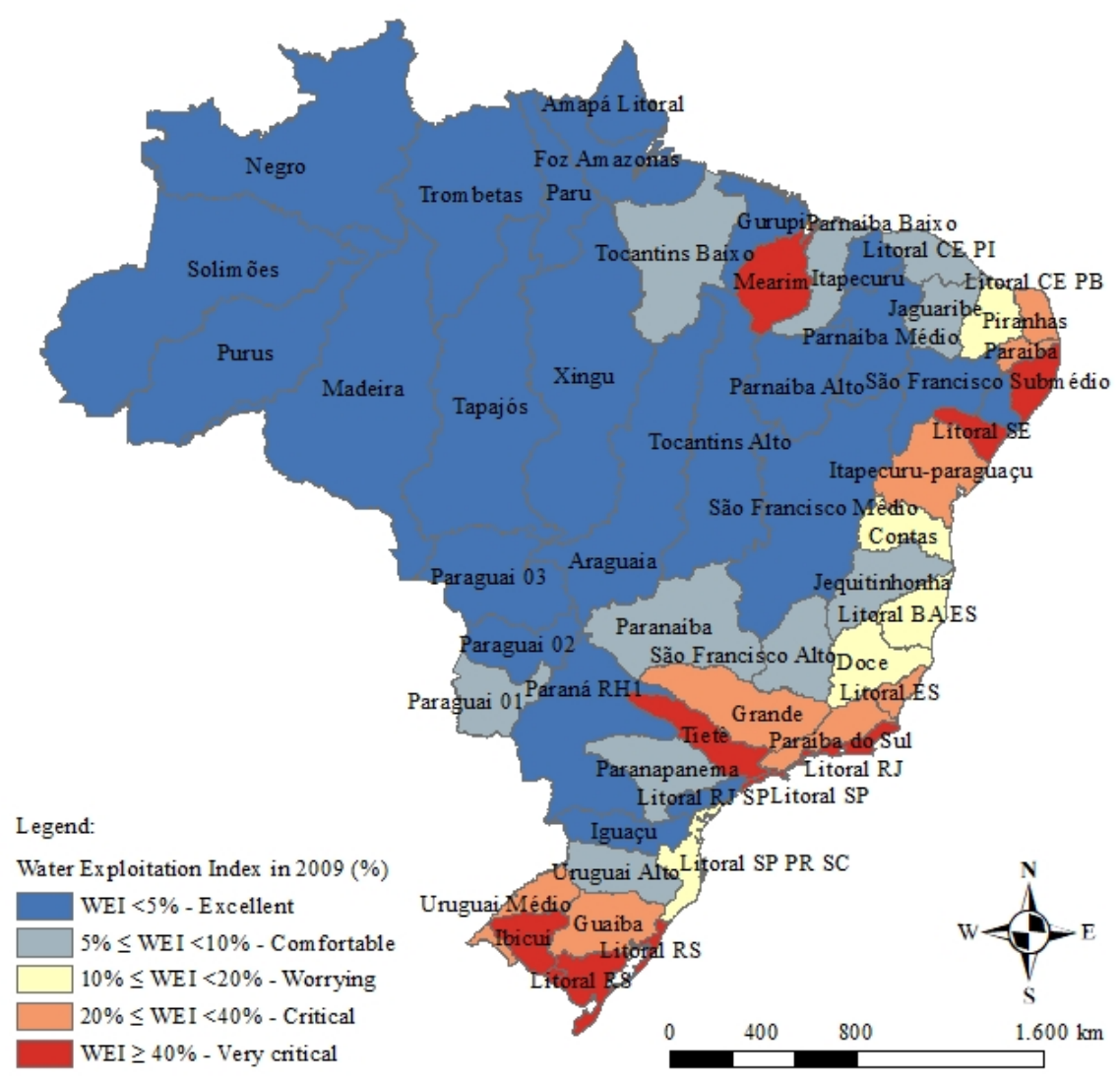

Source: Authors' calculations.

\section{CONCLUSIONS}

On the Blue Water Footprint by demand side, the Tietê hydrographic basin was the region with the greatest demand, which accounted for 14 percent $\left(8.7\right.$ billion $\left.m^{3}\right)$ in 2009. Tietê was followed by Litoral AL PE PB with 9 percent $\left(5.3\right.$ billion $m^{3}$ ). On the Blue Water Footprint supply side, the Litoral AL PE PB hydrographic basin was the greatest supplier accounting for 13 percent in 2009 .

Only seven watersheds were responsible for 52 percent of the Brazilian Virtual Blue Water demand. Eight regions provided 50 percent of the Brazilian Virtual Blue Water supply. The results underline that the national total water demand and supply is concentrated in a few watersheds located mainly in the southeast region.

In 2009, 60.6 billion $\mathrm{m}^{3}$ of Blue Water was withdrawn in Brazil, of which 61 percent was destined to the Virtual Blue Water interregional flows. Correspondingly, the Virtual Blue Water demand and supply flows among the Brazilian watersheds were mainly interregional in 2009. This highlights the cross-border nature of this natural resource.

From these results, we conclude that the water use in one Brazilian region influences 
water use and, consequently, water availability in other regions through the trade of goods and services. In this context, it is important to notice that Virtual Blue Water interregional imports can reduce the pressure on local water resources, whereas Blue Water Interregional exports can add to the local pressure on water. Therefore, to maintain water security, a positive relationship between WEI and WIDI and a negative relationship between WEI and WEDI are expected (Hoekstra and Hung, 2005).

For most of the regions with a WEI worrying, critical, or very critical situation, more than half of their Blue Water Footprint demand originated from the interregional imports of Virtual Blue Water. However, most of the regions with WEI challenges exported more than half of their withdrawn water volume. Sixty-six percent of the flows were exports from basins in which the water balance indicates potential water restrictions. Most of the Virtual Blue Water interregional export undermined local water availability. Therefore, a positive relationship between WEI and WIDI and between WEI and WEDI was shown in this research. In many cases, the Virtual Blue Water interregional supply undermines local water security.

This paper maps water flows throughout the Brazilian economy and identifies the origin and destination of water flows that cause restricted water availability. This mapping is especially important to the PNRH to answer questions such as: Who is directly generating the impact with its production? Who buys the products?

The presented approach can be employed to analyze the impacts of technological and economic changes, water pricing, and grant issuance on water use and, consequently, on the water balance within a regional framework. Such analysis enables institutions to better evaluate public policy on sustainable water use.

\section{REFERENCES}

Agência Nacional de Águas. (2009) "Conjuntura dos recursos hídricos no Brasil 2009," ANA: Brasília.

Agência Nacional de Águas. (2013a) "Conjuntura dos recursos hídricos no Brasil 2013," ANA: Brasília.

Agência Nacional de Águas. (2013b) Nível 1 de Sub-bacias do Plano Nacional de Recursos Hídricos.

Agência Nacional de Águas. (2018) Agência Nacional de Águas. Available online in May 2018 at http://www3.ana.gov.br/portal/ANA/panorama-das-aguas/ quantidade-da-agua $\ \% 3 \mathrm{E}$.

Allan, John Anthony. (1993) "Fortunately there are Substitutes for Water: Otherwise our Hydro-political Futures would be Impossible," Priorities for Water Resources Allocation and Management: London.

Chapagain, A. K. and A. Y. Hoekstra. (2003) "Virtual Water Flows between Nations in Relation to Trade in Livestock and Livestock Products," Value of Water - Research Report Series of UNESCO-IHE, 13.

Couto, S. E. R.. (2002) "Criação e manejo de coelhos," In Andrade, A.; Pinto, S. C.; Oliveira, R. S., ed., Animais de Laboratório: criação e experimentação. FIOCRUZ: Rio de Janeiro,

(C) Southern Regional Science Association 2019. 
p. 388.

da Silva, Vicente, Sonaly de Oliveira, Arjen Hoekstra, José Dantas Neto, João Campos, Célia Braga, Lincoln de Araújo, Danilo Aleixo, José de Brito, Márcio de Souza, and Romildo de Holanda. (2016) "Water Footprint and Virtual Water Trade of Brazil," Water, 8(11), 517.

Feng, Kuishuang, Ashok Chapagain, Sangwon Suh, Klaus Hubacek, and Santa Barbara. (2011) "Comparison of Bottom-up and Top-down Approaches to Calculating the Water Footprints of Nations," Economic Systems Research, 23(4), 371-385.

Fundação Banco do Brasil, Ministério do Meio Ambiente, and Fundação de Apoio à Universidade de Viçosa (Bank of Brazil Foundation; Ministry of Environment and the Support Foundation of the University of Viçosa). (2011) "Desenvolvimento de Matriz de Coeficientes Técnicos para Recursos Hídricos no Brasil: Relatório Final dos Coeficientes Técnicos de Recursos Hídricos das Atividades Industrial e Agricultura Irrigada," Relatório técnico, 6, 265p.

Gelain, J. G.. (2014). Volume de Água Virtual exportada pelo Brasil e por suas Unidades da Federação. Monography (bachelors of economics), State University of Maringá.

Guilhoto, Joaquim José Martins, Carlos Roberto Azzoni, Silvio Massaru Ichihara, Décio Kadota, and Eduardo Amaral Haddad. (2010) Matriz de Insumo-Produto do Nordeste e Estados: Metodologia e Resultados. Banco do Nordeste do Brasil, Fortaleza.

Guilhoto, Joaquim José Martins, Carlos Alberto Gonçalves Jr, Jaqueline Coelho Visentin, Denise Imori, and Keyi Ando Ussami. (2017) "Construção da Matriz Inter-regional de Insumo-produto para o Brasil: Uma aplicação do TUPI," TD NEREUS, 3.

Guilhoto, Joaquim José Martins and Umberto Antonio Sesso-Filho. (2005) "Estimação da Matriz Insumo-Produto a Partir de Dados Preliminares das Contas Nacionais," Economia Aplicada, 9(2), 277-299.

Hoekstra, A.Y. and P.Q. Hung. (2002) "Virtual Water Trade: A Quantification of Virtual Water Flows between Nations in Relation to International Crop Trade," Value of Water - Research Report Series of UNESCO-IHE, 11.

Hoekstra, Arjen Y, Ashok K Chapagain, Maite M Aldaya, and Mesfin M Mekonnen. (2011) The Water Footprint Assessment Manual: Setting the Global Standard. Earthscan.

Hoekstra, A. Y. and P. Q. Hung. (2005) "Globalisation of Water Resources: International Virtual Water Flows in Relation to Crop Trade," Global Environmental Change, 15(1), $45-56$.

Hoekstra, A. Y. and M. M. Mekonnen. (2012) "The Water Footprint of Humanity," Proceedings of the National Academy of Sciences, 109(9), 3232-3237.

Horochoski, Lucas, Giovana Katie Wiecheteck, and Maria Salete Marcon Gomes Vaz. (2011) "Avaliação do Coeficiente de Retorno de Esgoto na Bacia Hidrográfica do Arroio Gertrudes Ponta Grossa (PR)," Revista de Engenharia e Tecnologia, 3(1), 59-68.

Instituto Brasileiro de Geografia e Estatística (Brazilian Institute of Geography and Statistics). (2009) "Produção da Pecuária Municipal 2009," 37.

Instituto Brasileiro de Geografia e Estatística (Brazilian Institute of Geography and Statistics). (2010) Pesquisa Nacional de Saneamento Básico 2008. Rio de Janeiro.

Instituto Brasileiro de Geografia e Estatística (Brazilian Institute of Geography and Statistics). (2014) "Produção da Extração Vegetal e da Silvicultura," 29.

Instituto Brasileiro de Geografia e Estatística (Brazilian Institute of Geography and Statis-

(C)Southern Regional Science Association 2019. 
tics). (2015) Base Cartográfica Contínua do Brasil. Escala: 1:1000000.

Instituto Brasileiro de Geografia e Estatística (Brazilian Institute of Geography and Statistics).. (2015) Produção da Pecuária Municipal 2009.

Miller, R. E. and P.D. Blair. (2009) Input-output Analysis: Foundations and Extensions 2e. Cambridge University Press.

Ministério do Meio Ambiente. (2006) "Plano Nacional de Recursos Hídricos. v. 1, 2, 3 e 4," MMA: Brasília.

Operador Nacional do Sistema Elétrico and Consórcio Fahma/Dreer. (2005) "Estimativa das vazões para Atividades de Uso Consuntivo da água em Bacias do Sistema Interligado Nacional - SIN: Relatório Final - Metodologia e Resultados Consolidados," Operador Nacional do Sistema Elétrico: Brasília.

Picoli, I. T. (2016). Pegada Hídrica da economia brasileira: uma análise de insumo-produto. Dissertation (masters in economic development), Institute of Economics, State University of Campinas.

Schlosser, C. A., K. Strzepek, and X. Gao. (2014) "The Future of Global Water Stress: An Integrated Assessment," Earth's Future, 2(8), 341-361.

Secretaria Nacional de Saneamento Ambiental (National Secretariat of Environmental Sanitation). (2011) "Sistema Nacional de Informações sobre Saneamento - SNIS: Diagnóstico dos Serviços de Água e Esgotos - 2009," SNSA: Brasília.

Shiklomanov, I.. (1993) "World fresh water resources," In Gleick, P. H., ed., Water in Crisis: A Guide to the World's Fresh Water Resources. Oxford University Press: New York.

United Nations Environment Programme 2e. (2008) An Overview of the State of the World's Fresh and Marine Waters. Nairobi.

Ussami, Keyi Ando and Joaquim José Martins Guilhoto. (2018) "Economic and Water Dependence among Regions: The Case of Alto Tiete, Sao Paulo State, Brazil," EconomiA, 19(3), 350-376.

Zimmer, D. and D. Renault. (2003) "Virtual Water in Food Production and Global Trade: Review of Methodological Issues and Preliminary Results," In Hoekstra, A. Y., ed., Virtual Water Trade: Proceedings of the International Expert Meeting on Virtual Water Trade. Value of Water Research Report Series, n.12 UNESCO-IHE: Delft.

(C)Southern Regional Science Association 2019. 


\section{APPENDIX}

\section{Appendix A}

Table 2: Acronyms Description

\begin{tabular}{lrl}
\hline \hline Water Exploitation Index & $W E I_{b}$ & $W E I_{b}=W_{b} / W_{a b}$ \\
Where & & \\
" $b$ " is basin & & \\
$W E I_{b}$ is water withdrawan in basin " $b "$ & & \\
$\quad W_{a b}$ is water availability in basin " $b "$ & $W I D I$ & $W I D I=W F_{\text {imp }} / W F_{d}$ \\
Water Import Dependency Index & $W E D I$ & $W E D I=W F_{\text {exp }} / W F_{s}$ \\
\hline
\end{tabular}

Source: Authors

\section{Appendix B}

$$
\text { Coef_withdrawal } c(l / m)=\text { Coef_withdrawal }_{c b}(l / s) * 2,592,000
$$

Qwithdrawal $_{c b}(l / m)=$ Coef_withdrawal ${ }_{c b}(l / m) *$ Irrigated_area in a month $_{c b}(h a)$

$$
\begin{gathered}
\operatorname{Qwithdrawal}_{c b}(l / y)=\sum_{\text {month=1 }}^{12} Q_{\text {withdrawal }}(l / m)_{\text {month }} \\
\text { Qwithdrawal }_{c b}\left(m^{3} / y\right)^{8}=\text { Qwithdrawal }_{c b}(l / y) / 1,000
\end{gathered}
$$

Where:

Coef_withdrawal ${ }_{c b}(l / m)$ : water withdrawal coefficient for irrigation of crop "c" in basin "b" in liters per month $(\mathrm{l} / \mathrm{m})$;

Coef_withdrawal $c b(l / s):$ : water withdrawal coefficient for irrigation of crop "c" in basin "b" in liters per second $(\mathrm{l} / \mathrm{s})$;

2,592,000: number of seconds in a month of 30 days;

Qwithdrawal $(l / m)$ : water withdrawal flow for crop "c" in basin "b" in $\mathrm{l} / \mathrm{m}$;

Irrigated_area in a month $h_{c b}(h a)^{9}$ : irrigated area in crop "c" of the basin "b," in hectare (ha);

${ }^{8}$ The calculations were analogous to the direct technical coefficients and to the consumption and return of water flows

${ }^{9}$ For the calculation of the direct technical coefficients of water use by agricultural crops, no increase in the irrigated area between 2006 and 2009 was assumed (2006 was the year of the last Brazilian Agricultural Census, which provides information on the irrigated area; the interregional input-output matrix is based on estimates for 2009). The analysis requires the structure of water use and the economic and water interdependence among the basins. The different reference years was considered not to undermine the 
Qwithdrawal ${ }_{c b}(l / y)$ : water withdrawal flow of crop "c" in basin "b," in liters per year $(\mathrm{l} / \mathrm{y})$

Qwithdrawal ${ }_{c b}\left(\mathrm{~m}^{3} / y\right)$ : volume of water withdrawal from crop "c" in basin "b," in cubic meters per year $\left(m^{3} / y\right)$.

Given that the model is a sector by sector system further adjustments were necessary. The 59 agricultural products had to be aggregated to nine agricultural sectors.

Thus, the Blue Water $\left(\mathrm{m}^{3} / y\right)$ used by the agriculture sectors of each basin for 2009 was obtained. Then, the direct technical coefficients of Blue Water use to agricultural activities was estimated as follows:

$$
C D A_{s b}\left(m^{3} / M R \$\right)=Q w i t h d r a w a l_{s b}\left(m^{3} / y\right) / G V P_{s b}(M R \$)
$$

Where:

$C D A_{s b}\left(m^{3} / M R \$\right)$ : direct technical coefficient of Blue Water withdrawal of sector "s" located in basin "b," measured in cubic meters per million of Reais $\left(m^{3} / M R \$\right)$ of 2009 ;

Qwithdrawal ${ }_{s b}\left(\mathrm{~m}^{3} / y\right)$ : water withdrawal volume referring to the sector "s" of the basin "b," in $m^{3} / y$;

$G V P_{s b}(M R \$)$ : Gross Value of Production (GVP) of sector "s" located in watershed "b," measured in millions of Reais (MR $\$$ ) of 2009, obtained according to the estimated interregional input-output matrix.

\section{Appendix C}

Firstly, data on the Blue Water withdrawal rate and Blue Water return rate per animal species were used according to the Operador Nacional do Sistema Elétrico and Consórcio Fahma/Dreer (2005), as well as in Couto (2002). This data was combined with the herd size available from the IBGE 2009 Municipal Livestock Research (PPM) (Instituto Brasileiro de Geografia e Estatística (Brazilian Institute of Geography and Statistics), 2009; Instituto Brasileiro de Geografia e Estatística (Brazilian Institute of Geography and Statistics)., 2015). The direct technical coefficients of Blue Water use, in $m^{3} / M R \$$, of the livestock sectors were estimated as follows:

$$
\begin{gathered}
Q w_{b}^{h}(l / d)=H e r d_{b}^{h} * q^{h} \\
Q r_{b}^{h}(l / d)=Q w_{b}^{h}(l / d) * k \\
Q c_{b}^{h}(l / d)=Q w_{b}^{h}(l / d) * Q r_{b}^{h}(l / d)
\end{gathered}
$$

validity of the results, so that the methodology of Ussami and Guilhoto (2018) was applied. Two other estimation options were evaluated for updating the irrigated area of the basins: (i) based on the ratio between irrigated area and harvested area in 2006 extrapolated to 2009 based on the 2009 harvested area; and (ii) projecting the irrigated area of 2009 based on the growth rate of previous years. It was decided not to proceed with these approaches, as according to ANA, the results would lack reliability. According to the agency, there is no correlation between the evolution of the irrigated area and crops. Also, irrigated pastures are counted as irrigated area but not as crops (Agência Nacional de Águas, 2009).

(c)Southern Regional Science Association 2019. 
Where:

The subscript "b" distinguishes the basins and the superscript "h" distinguishes the types of herd;

$l / d$ : Liters per day;

$Q w_{b}^{h}$ : water withdrawal flow for herd type "h" in basin "b";

$\operatorname{Herd}_{b}^{h}$ : size of herd "h" in 2009 in basin "b";

$q^{h}$ : per capita water withdrawal rate per herd type "h";

$Q r_{b}^{h}$ : water return flow for herd "h" in basin "b";

$k$ : rate of water return;

$Q c_{b}^{h}$ : water consumption flow from herd "h" in basin "b" in 2009.

The Blue Water withdrawal, consumption and return flows were estimated according to the type of herd in each hydrographic basin in 2009. Its measurement units were transformed from $l / d$ to $m^{3} / y$. The water flow used per herd type was transformed into the water volume used by the livestock sectors.

Finally, this data was divided by the 2009 GVP of the respective sectors. The direct technical coefficients of water use for the livestock sectors, therefore, reflect the different compositions of the herds in the regions.

\section{Appendix D}

The Blue Water use's direct technical coefficients of industrial activities (sectors 16-37) were obtained from Ussami and Guilhoto (2018). Ussami's database provides the direct technical coefficients of Blue Water use for 59 industrial sectors in Brazil, which are an adaptation of the data available in Fundação Banco do Brasil et al. (2011). Coefficients in form of $m^{3}$ per physical unit, such as tons, Ussami and Guilhoto (2018) converted to $m^{3} / M R \$ 2009$.

As, however, Ussami's direct technical coefficients are for the national industry and this research analyses 21 industrial sectors of 56 hydrographic basins, the data was adjusted.

To reflect the heterogeneities of the regional industries, Ussami's direct technical coefficients of water use of 50 (out of 59) national industrial activities were aggregated by weighted average to direct technical coefficients of water use of 12 regional industrial activities. This estimation was weighted by GVP corresponding to each basin's industrial activities ${ }^{10}$.

In this way the direct technical coefficients of water use for 12 regionalized industrial sectors were obtained for the hydrographic basins. The water use coefficients of the other nine industrial activities of each watershed remained the same as the national coefficients calculated by Ussami and Guilhoto (2018).

\section{Appendix E}

${ }^{10}$ The industrial activities' GVP of each basin was estimated by aggregating industrial activities' GVP of each municipality. The industrial activities' GVP at the municipal level for 2009 were extracted from the interregional input-output system, which was estimated according to the methodologies available in Guilhoto and Sesso-Filho (2005); Guilhoto et al. (2010) and Guilhoto et al. (2017).

(C)Southern Regional Science Association 2019. 
For the estimation of the direct coefficient of water use by the water and sewage sector (sector 42), the following methodology was employed:

$$
\begin{gathered}
V R_{2009}=1,048 * V R_{2008} \\
V C_{2009}=V R_{2009} *(1-I P D) \\
V_{\text {Return }} 2009=V C_{2009} * C_{r}
\end{gathered}
$$

Where:

$V R_{2009}$ : Volume of water withdrawal in each municipality in 2009 for public supply purposes;

4.8 percent: Rate of annual average growth of water volume for supply purposes (between 2008 and 2009). It was estimated according to information available in the National Survey of Basic Sanitation (PNSB) (Instituto Brasileiro de Geografia e Estatística (Brazilian Institute of Geography and Statistics), 2010);

$V R_{2008}$ : Volume of water collected in each municipality in 2008 for public supply purposes;

$V C_{2009}$ : Volume of water, supplied by public system, consumed in each basin in 2009. $V R_{2009}$ by hydrographic basin was estimated by aggregating respective municipals to the watershed level;

IPD: Distribution Loss Index in each hydrographic basin in 2009. This data is available by UF according to Secretaria Nacional de Saneamento Ambiental (National Secretariat of Environmental Sanitation) (2011). It was assumed that the municipal IPDs was equal to the UFs IPDs;

VReturn $n_{2009}$ : The volume of water returned to public basic sanitation service of each hydrographic basin in 2009;

$C_{r}$ : Return coefficient equal to 0.8, according to the Brazilian Standard 9,649/1986 of the Brazilian Association of Technical Standards (ABNT) (Horochoski et al., 2011).

Finally, the data was divided by the 2009 GVP sector to obtain the direct technical coefficients of water use of the water and sewage sector of each watershed.

(C)Southern Regional Science Association 2019. 